\title{
Prioritization of Customer Service Quality Dimensions in Indian Cooperative Banks: RIDIT \& Grey Relational Approach
}

\author{
Sona Srivastava ${ }^{1}$, Rama Koteshwara Rao Kondasani ${ }^{2} \&$ Amit Kumar Masih $^{1}$ \\ ${ }^{1}$ Department of Agriculture Economics, Sam Higginbottom University of Agriculture, Technology and Sciences, \\ Allahabad, India \\ ${ }^{2}$ Department of Management Studies, National Institute of Technology, Silchar, India \\ Correspondance: Dr. Rama Koteswara Rao Kondasani Department of Management Studies, National Institute of \\ Technology, Silchar, India.
}

Received: September 8, 2020

Accepted: November 10, 2020

Online Published: May 6, 2021

doi:10.5430/rwe.v12n3p42

URL: https://doi.org/10.5430/rwe.v12n3p42

\begin{abstract}
The principal objective of this research paper is to Prioritise Customer Perceived Service Quality (CPSQ) in the proportion of service quality for Indian cooperative banking sector. In order to understand the cooperative banking customer's perspective and their relative significance, thirty three service quality dimensions are considered and deeply analysed. In addition, Questionnaire of Customer Perceives Service Quality (CPSQ) is also collected and implemented. Here, the necessary data is collected in the months of November 2019 and January 2020 respectively by using convenience sampling method. The data is collected from the state of Utter Pradesh, India. The reason behind choosing Utter Pradesh is, it agriculturally strong and has higher population (around 20 Crores) in India. Here, to prioritise the CPSQ scale, we have used Relative to an Identified Distribution (RIDIT) \& Grey Relational Analysis (GRA) and later we also compared the results to check the reliability of these ranking methods. To perform this prioritization we have used seven factors such as Efficiency (EFF); Infrastructure (INF); Effectivenes (EFT); Timely Services (TMS); Bank Image (BIG); Safety \& Security (SS) and Up to date technology (UDT). Later, GRA and RIDIT analysis are also conducted to distinguish the prioritization of service quality items. The present study and analysis helps to validate the cooperative banks service quality in general by ranking the service quality dimensions, which are specifically important in Indian banking sector to improve and enhance its quality. Finally, the obtained results shows that, it is apparent that managers of cooperative banks in Indian scenario must focus more on cooperative bank quality dimensions to improve the reliability of their customer's perception of cooperative banking in terms of better performance and service quality.
\end{abstract}

Keywords: Customer Perceived Service Quality (CPSQ), cooperative banks, prioritizations, GREY analysis, RIDT analysis, Uttar Pradesh, India

\section{Introduction}

Usually, the unsatisfied customer of any existing service provider changes their service environment at any time (Garland, 2002). It happens to be permanent and sometimes limited (Colgate and Hedge, 2001). In recent times, Indian banking industry is engaged with big number of small banks particularly with cooperative branches. Particularly, by considering the Indian cooperative banking scenario, it would be permanent most of the time. Indian cooperative bank customers generally maintain single accounts to their bank. It indicates that, if customer moving from existing one to new one then, it may causes to lose the customer base. In fact, detecting the customers who permanently moved is not much difficult because they close all their existing account and open their new service provider (Bolton and Bronkhorst, 1995; Boote, 1998). But where as in Indian banking scenario it is very difficult to shift from one cooperative bank to another cooperative bank. So, the customers in the current scenario shift their service provider from cooperative bank to other private sector banks. Here, there is a need of attention to focus and indentify the customer's preferences and requirements by the existing service providers.

In this context, the present research study examines various service quality dimensions in Indian cooperative banks perspective. The resultant analysis may help the banking service provider to identify the various service quality dimensions which are necessarily important in terms of customer perception. The proposed research work will provide useful insights to service providers of the cooperative banks, policy makers, managers, marketing 
researchers, also to the top management to frame useful policies for their customers, which may minimise the customers' moment from banks.

\section{Literature Review}

The theory of customer service quality refered as, to what extent the customer's service expectations are fulfilled by the service provider (Parasuraman et al., 1985). SERVQUAL is one of the highly accepted theories of service quality. SERVQUAL is the multi-item dimensional instrument that captures the gap between the customer expectation and customer perception among multiple service quality determinants (Butt and de Run, 2010; Akdag and Zineldin, 2011; Azam et al., 2012; Choudhury, 2013; Panda and Kondasani, 2014). Parasuraman, Zeithaml and Berry (1988) defined that, SERVQUAL can be administered across varied service contexts to analyse and fill the gap in service quality across five factors namely "tangibility, reliability, responsiveness, assurance, and empathy". The researchers examined the argument of the five dimensional structure of the service quality theory, and debated that service quality is appropriate, and it is important to scrutinise the nature of service quality across numerous services settings (Cronin and Taylor, 1992; Bouman and van der Wiele, 1992; Gagliano and Hathcote, 1994; Ekinci and Riley, 1999).

In previous studies, few of various researchers have identified various service quality dimensions that determined customer satisfaction in the banking sector and also identified a lot of differences in the way consumers observe services across different regions and cultures specially in developed nations. One of the important research in this scenarios, such as Levesque and McDougall (1996) highlighted that convenience and competitiveness of the institution were the two most important dimensions that are likely to effect the overall satisfaction levels of specific institution of customer. In developed nations like Malaysia and United Arab Emirates (UAE) some banks identified few key services which are also satisfied by the customers such as fast and well-organized service, sociability of bank employees /personel, secrecy/confidentiality, and rapid transaction (Amin and Isa, 2008). The service provider's ability to deliver the same key services consistently and definitely will impact the level of customer satisfaction in any organisation. Due to this reason, each service provider needs to maintain and expand their customer base to succeed in their respective business and banking. In the recent times, the scope of Indian banking sector is prominently increasing each year and also adjacently lot more players are entering into this sector including digital payments and as well as instant loan approval agencies. So, it is more important for Indian banking sector to understand the evaluation criteria by the modern consumers and to have a proper system by which consumers should stick with them for long term through high satisfaction as well. By taking those points in to consideration, our research is highly focused and have taken the followed factors for prioritising customer service quality dimensions are Efficiency (EFF); Infrastructure (INF); Effectiveness (EFT); Timely Services (TMS); Bank Image (BIG); Safety \& Security (SS); Up to date technology (UDT).

Usually, in the banking sector organisation image is an attitude that replicates various product characteristics of an organisation. In the perspective of the organisation, it's image is the close link which will come as a first thought when consumers hear the title of its organization (Flavian et al., 2004; Nguyen and Leclerc, 2011). According to kennedy (1997) the image of any organisation has two principal modules: functional and emotional. The functional module is related to physical dimensions that can be identified and measured in easy way, while the emotional module is associated with the psychosomatic way. However, many researches and researchers has agreed that, the organisation image is the outcome of a process; therefore, company image is the outcome of cumulative procedure by which customers match and contrast the various elements of organisation (Bravo et al., 2009; Nguyen and LeBlanc, 2001). According to Kang and James (2004), organisation image is observed as a strainer in terms of a customer's perception of service quality. Thus, organisation image is the result of all experiences, impressions, beliefs, feelings, and awareness that customers have about a company (Hsiong-Ming et al., 2011). Based on all the literature studies, we have considered bank image is one of the important factors in our scenario.

\section{Respondents Profile}

Here, data was collected from the customers of Indian cooperative banks, where different locations of largest (Population wise) state i.e., Uttar Pradesh. The profile of the respondents is listed in (Table-1). Out of the complete questionnaires filled in, $72.9 \%$ were males and $27.1 \%$ females. The point to notice here is, the percentage difference between male and female respondents is high; the traditional reason behind this is males have a dominant role in the rural India especially in the matters of financial and banking sector. Later, by considering the educational qualification, $21.78 \%$ of the respondents went to primary level, $39.39 \%$ were at secondary level, around $19 \%$ were graduates and post graduates and above qualification. This significantly showing that $40 \%$ of our research questionnaire was filled by the educated customers. 
Table 1. Demographic profile of the samples

\begin{tabular}{|c|c|c|c|}
\hline Demographic Characteristics & Variables & Frequency & $\%$ \\
\hline \multirow{2}{*}{ Gender } & Male & 381 & 72.9 \\
\hline & Female & 141 & 27.1 \\
\hline \multirow{4}{*}{ Respondent Education } & Primary education & 115 & 21.78 \\
\hline & Secondary education & 208 & 39.39 \\
\hline & Graduates & 101 & 19.13 \\
\hline & $>$ post-graduation & 104 & 19.70 \\
\hline \multirow{3}{*}{$\begin{array}{l}\text { Income Range of the } \\
\text { Respondents }\end{array}$} & $<$ Rs. 99,000 & 298 & 56.44 \\
\hline & Rs. $1,00,000$ to $4,99,999$ & 168 & 31.82 \\
\hline & $>$ Rs. $5,00,000$ & 62 & 11.74 \\
\hline \multirow{4}{*}{ Qualification } & Primary (up to $5^{\text {th }}$ Standard) level & 115 & 21.78 \\
\hline & Secondary $\left(6^{\text {th }}\right.$ to +2$)$ level & 208 & 39.39 \\
\hline & Graduation & 101 & 19.13 \\
\hline & Above Graduation (Professional) & 104 & 19.70 \\
\hline
\end{tabular}

\section{Data Analysis}

\subsection{Analysis of RIDIT}

In the year of 1958, Bross was proposed RIDIT analysis and applied the same in numerous business and behaviour research performance studies. The term "RIDIT" is termed as "Relative to an Identified Distribution" and is a likelihood transformation based on some empirical distributions that is taken as a reference class. RIDIT analysis is "distribution free", which means no assumption about the distribution of the population of the research sample (Fleiss et al. 2003). RIDIT is a procedure aimed to support in the investigation of samples or data containing items that are more than characterising categorisations and are well-arranged and that do not reach the standards of refined measurement systems such as those meeting the criteria for equalit-interval or ratio scales (Panda \& Sreekumar 2012). RIDIT analysis is very useful statistical method and analysis for items comprising ratings on a 3 or more point scale, indices made up of a number of items and ratings based on universal ratings (Beder\& Heim, 1990).The RIDIT number is assigned to a certain set of the variable that is equivalent to the fraction of the reference group which have a lower score on that specific item, plus one-half of the proportion of individuals in the category itself. Then RIDIT is a "weight assigned to a response category that reflects the probability of that category appearing in the reference distributions". A RIDIT has a range that approaches the limits of 0.00 at one end and 1.00 at the other end. In RIDIT analysis, researchers compute an average RIDIT value for a group rather than the proportion of respondents giving each of the responses in the dependent item.

Table 2. RIDITs for service quality items

\begin{tabular}{lllllllll}
\hline Items & $\mathbf{7}$ & $\mathbf{6}$ & $\mathbf{5}$ & $\mathbf{4}$ & $\mathbf{3}$ & $\mathbf{2}$ & $\mathbf{1}$ & $\begin{array}{c}\text { Total } \\
\text { Sample }\end{array}$ \\
\hline EFF-1 & 19 & 312 & 104 & 0 & 35 & 52 & 0 & 522 \\
\hline EFF-2 & 19 & 220 & 154 & 0 & 78 & 51 & 0 & 522 \\
\hline EFF-3 & 16 & 285 & 120 & 0 & 46 & 55 & 0 & 522 \\
\hline EFF-4 & 12 & 270 & 119 & 0 & 67 & 54 & 0 & 522 \\
\hline EFF-5 & 12 & 271 & 134 & 0 & 50 & 55 & 0 & 522 \\
\hline EFF-6 & 147 & 221 & 91 & 43 & 20 & 0 & 0 & 522 \\
\hline
\end{tabular}




\begin{tabular}{|c|c|c|c|c|c|c|c|c|}
\hline INF-1 & 151 & 201 & 94 & 47 & 26 & 3 & 0 & 522 \\
\hline INF-2 & 133 & 199 & 108 & 52 & 24 & 3 & 3 & 522 \\
\hline INF-3 & 147 & 233 & 82 & 39 & 20 & 1 & 0 & 522 \\
\hline INF-4 & 102 & 167 & 114 & 67 & 54 & 12 & 6 & 522 \\
\hline INF-5 & 127 & 214 & 103 & 44 & 30 & 1 & 3 & 522 \\
\hline EFT-1 & 108 & 284 & 71 & 52 & 7 & 0 & 0 & 522 \\
\hline EFT-2 & 112 & 287 & 60 & 51 & 10 & 0 & 2 & 522 \\
\hline EFT-3 & 102 & 288 & 73 & 46 & 9 & 4 & 0 & 522 \\
\hline EFT-4 & 79 & 235 & 89 & 104 & 12 & 3 & 0 & 522 \\
\hline EFT-5 & 107 & 285 & 81 & 38 & 8 & 2 & 1 & 522 \\
\hline TMS-1 & 150 & 278 & 54 & 27 & 12 & 1 & 0 & 522 \\
\hline TMS-2 & 125 & 288 & 67 & 36 & 6 & 0 & 0 & 522 \\
\hline TMS-3 & 187 & 253 & 56 & 23 & 3 & 0 & 0 & 522 \\
\hline TMS-4 & 115 & 296 & 74 & 32 & 5 & 0 & 0 & 522 \\
\hline TMS-5 & 135 & 307 & 47 & 30 & 3 & 0 & 0 & 522 \\
\hline BIG-3 & 133 & 201 & 87 & 71 & 23 & 3 & 4 & 522 \\
\hline BIG-4 & 154 & 180 & 55 & 103 & 24 & 4 & 2 & 522 \\
\hline BIG-2 & 121 & 223 & 80 & 83 & 12 & 0 & 3 & 522 \\
\hline BIG-1 & 145 & 211 & 60 & 83 & 19 & 3 & 1 & 522 \\
\hline SS-1 & 133 & 177 & 106 & 56 & 37 & 10 & 3 & 522 \\
\hline SS-2 & 116 & 185 & 115 & 64 & 35 & 4 & 3 & 522 \\
\hline SS-3 & 114 & 168 & 118 & 68 & 39 & 9 & 6 & 522 \\
\hline SS-4 & 140 & 167 & 123 & 50 & 29 & 10 & 3 & 522 \\
\hline UDT-1 & 48 & 231 & 34 & 0 & 49 & 131 & 29 & 522 \\
\hline UDT-2 & 107 & 264 & 21 & 0 & 38 & 82 & 9 & 522 \\
\hline UDT-3 & 127 & 234 & 32 & 0 & 40 & 82 & 7 & 522 \\
\hline UDT-4 & 73 & 286 & 42 & 0 & 51 & 60 & 10 & 522 \\
\hline $\mathrm{Fi}$ & 3516 & 7921 & 2768 & 1309 & 921 & 695 & 95 & 17225 \\
\hline $1 / 2 \mathrm{Fi}$ & 1758 & 3960.5 & 1384 & 654.5 & 460.5 & 347.5 & 47.5 & \\
\hline $\mathrm{Rj}$ & 1758 & 7476.5 & 12821 & 14859.5 & 15974.5 & 16782.5 & 17177.5 & \\
\hline ri & 0.10211 & 0.4340494 & 0.7443252 & 0.862671 & 0.9274021 & 0.97432 & 0.997243 & \\
\hline
\end{tabular}


Table 3. Comparison data sets and prioritisation for CPSQ items

\begin{tabular}{|c|c|c|c|c|c|c|c|c|c|}
\hline Items & 7 & 6 & 5 & 4 & 3 & 2 & 1 & Priority Rating & Rank \\
\hline EFF-1 & 0.004 & 0.259 & 0.148 & 0.000 & 0.062 & 0.097 & 0.000 & 0.571 & 28 \\
\hline EFF-2 & 0.004 & 0.183 & 0.220 & 0.000 & 0.139 & 0.095 & 0.000 & 0.640 & 33 \\
\hline EFF-3 & 0.003 & 0.237 & 0.171 & 0.000 & 0.082 & 0.103 & 0.000 & 0.596 & 29 \\
\hline EFF-4 & 0.002 & 0.225 & 0.170 & 0.000 & 0.119 & 0.101 & 0.000 & 0.616 & 31 \\
\hline EFF-5 & 0.002 & 0.225 & 0.191 & 0.000 & 0.089 & 0.103 & 0.000 & 0.610 & 30 \\
\hline EFF-6 & 0.029 & 0.184 & 0.130 & 0.071 & 0.036 & 0.000 & 0.000 & 0.449 & 7 \\
\hline INF-1 & 0.030 & 0.167 & 0.134 & 0.078 & 0.046 & 0.006 & 0.000 & 0.460 & 11 \\
\hline INF-2 & 0.026 & 0.165 & 0.154 & 0.086 & 0.043 & 0.006 & 0.006 & 0.485 & 16 \\
\hline INF-3 & 0.029 & 0.194 & 0.117 & 0.064 & 0.036 & 0.002 & 0.000 & 0.441 & 6 \\
\hline INF-4 & 0.020 & 0.139 & 0.163 & 0.111 & 0.096 & 0.022 & 0.011 & 0.562 & 27 \\
\hline INF-5 & 0.025 & 0.178 & 0.147 & 0.073 & 0.053 & 0.002 & 0.006 & 0.483 & 15 \\
\hline EFT-1 & 0.021 & 0.236 & 0.101 & 0.086 & 0.012 & 0.000 & 0.000 & 0.457 & 10 \\
\hline EFT-2 & 0.022 & 0.239 & 0.086 & 0.084 & 0.018 & 0.000 & 0.004 & 0.452 & 8 \\
\hline EFT-3 & 0.020 & 0.239 & 0.104 & 0.076 & 0.016 & 0.007 & 0.000 & 0.463 & 12 \\
\hline EFT-4 & 0.015 & 0.195 & 0.127 & 0.172 & 0.021 & 0.006 & 0.000 & 0.537 & 25 \\
\hline EFCT-5 & 0.021 & 0.237 & 0.115 & 0.063 & 0.014 & 0.004 & 0.002 & 0.456 & 9 \\
\hline TMS-1 & 0.029 & 0.231 & 0.077 & 0.045 & 0.021 & 0.002 & 0.000 & 0.405 & 3 \\
\hline TMS-2 & 0.024 & 0.239 & 0.096 & 0.059 & 0.011 & 0.000 & 0.000 & 0.430 & 4 \\
\hline TMS-3 & 0.037 & 0.210 & 0.080 & 0.038 & 0.005 & 0.000 & 0.000 & 0.370 & 1 \\
\hline TMS-4 & 0.022 & 0.246 & 0.106 & 0.053 & 0.009 & 0.000 & 0.000 & 0.436 & 5 \\
\hline TMS-5 & 0.026 & 0.255 & 0.067 & 0.050 & 0.005 & 0.000 & 0.000 & 0.404 & 2 \\
\hline BIG-3 & 0.026 & 0.167 & 0.124 & 0.117 & 0.041 & 0.006 & 0.008 & 0.489 & 18 \\
\hline BIG-4 & 0.030 & 0.150 & 0.078 & 0.170 & 0.043 & 0.007 & 0.004 & 0.482 & 14 \\
\hline BIG-2 & 0.024 & 0.185 & 0.114 & 0.137 & 0.021 & 0.000 & 0.006 & 0.487 & 17 \\
\hline BIG-1 & 0.028 & 0.175 & 0.086 & 0.137 & 0.034 & 0.006 & 0.002 & 0.468 & 13 \\
\hline SS-1 & 0.026 & 0.147 & 0.151 & 0.093 & 0.066 & 0.019 & 0.006 & 0.507 & 21 \\
\hline SS-2 & 0.023 & 0.154 & 0.164 & 0.106 & 0.062 & 0.007 & 0.006 & 0.522 & 23 \\
\hline SS-3 & 0.022 & 0.140 & 0.168 & 0.112 & 0.069 & 0.017 & 0.011 & 0.540 & 26 \\
\hline SS-4 & 0.027 & 0.139 & 0.175 & 0.083 & 0.052 & 0.019 & 0.006 & 0.500 & 19 \\
\hline UDT-1 & 0.009 & 0.192 & 0.048 & 0.000 & 0.087 & 0.245 & 0.055 & 0.637 & 32 \\
\hline UDT-2 & 0.021 & 0.220 & 0.030 & 0.000 & 0.068 & 0.153 & 0.017 & 0.509 & 22 \\
\hline UDT-3 & 0.025 & 0.195 & 0.046 & 0.000 & 0.071 & 0.153 & 0.013 & 0.503 & 20 \\
\hline UDT-4 & 0.014 & 0.238 & 0.060 & 0.000 & 0.091 & 0.112 & 0.019 & 0.534 & 24 \\
\hline
\end{tabular}


Since the $\mathrm{W}$ value is 927.9758821 is significantly more than $\chi^{2}(33-1)=46.194$, it can conclude that the responses about the RIDIT measure items between the different samples are statistically different.

\subsection{Grey Relation Analysis (GRA)}

Grey System was first developed by Deng (1982). GRA is much suitable for solving multi objective optimization problems. In modern machining procedure, optimization technique is used to find the optimal values of the response parameter and the correlation that effect on response variable (Phimoolchat and Muttamara2020). The rationality of traditional statistical exploration methods is based on assumption such as the distribution of population and variations of samples. The term "Grey" stands for poor, incomplete and uncertain, and is especially used in relation to the concept of information (Huang, 2010). Grey Relational Analysis (GRA), is a part of Grey Theory, and a kind of method by which the relational degree of every factor in the system can be analyzed (Meng\&Kees, 2007). GRA indicates the relational degree between two measurement sequences by using the discrete measurement method to measure the spaces (Huang, 2010). GRA is used to form a level and recommend a finest alternative on a group of choices (Debata et al, 2010). Grey Relation Analysis uses existing information from the Grey system to vigorously match influence dimensions quantitatively and it is constructed on the level of comparison and inconsistency among total dimensions to establish their structured relation.

Table 4. Grey Relational Grade and ranking of customer perceived service quality in cooperative banks

\begin{tabular}{|c|c|c|c|c|c|c|c|c|c|c|c|c|c|c|c|c|c|}
\hline EFF-1 & 1 & 0.75 & 1 & 1 & 0.75 & 0.75 & 0.75 & - & - & 0.75 & 0.75 & 0.75 & 0.75 & 0.75 & 0.75 & 0.6703 & 28 \\
\hline EFF-2 & 1 & 1 & 1 & 1 & 1 & 0.75 & 1 & - & - & 0.375 & 0.75 & 0.75 & 0.75 & 0.75 & 0.75 & 0.6302 & 32 \\
\hline EFF-3 & 0.75 & 0.75 & 0.75 & 0.75 & 0.75 & 0.75 & 0.75 & - & - & 0.42857 & 0.75 & 0.75 & 0.75 & 0.75 & 0.75 & 0.6553 & 29 \\
\hline EFF-4 & 0.75 & 0.75 & 0.75 & 0.75 & 0.75 & 0.75 & 0.75 & - & - & 0.42857 & 0.75 & 0.75 & 0.42857 & 0.75 & 0.75 & 0.6415 & 31 \\
\hline EFF-5 & 0.75 & 1 & 0.75 & 0.75 & 0.75 & 0.75 & 1 & - & - & 0.42857 & 0.42857 & 0.75 & 0.75 & 0.75 & 0.75 & 0.6469 & 30 \\
\hline EFF-6 & 0.75 & 1 & 0.75 & 0.75 & 0.75 & 0.5 & 0.75 & - & - & 1 & 0.75 & 0.75 & 1 & 0.75 & 0.6 & 0.7613 & 7 \\
\hline INF-1 & 0.75 & 0.75 & 0.75 & 1 & 1 & 0.75 & 0.75 & - & - & 1 & 0.75 & 0.6 & 0.5 & 0.42857 & 0.42857 & 0.7546 & 8 \\
\hline INF-2 & 1 & 1 & 0.75 & 0.6 & 0.75 & 0.6 & 0.75 & - & - & 1 & 0.6 & 1 & 0.5 & 0.75 & 0.5 & 0.7384 & 16 \\
\hline INF-3 & 0.75 & 0.75 & 0.75 & 0.75 & 0.75 & 0.75 & 0.75 & - & - & 0.75 & 0.75 & 0.75 & 0.75 & 0.75 & 0.6 & 0.7651 & 6 \\
\hline INF-4 & 1 & 0.75 & 0.75 & 0.6 & 1 & 0.75 & 0.75 & - & - & 0.6 & 0.6 & 1 & 0.5 & 1 & 0.6 & 0.6873 & 27 \\
\hline INF-5 & 0.75 & 1 & 0.75 & 0.75 & 0.42857 & 0.75 & 0.75 & - & - & 1 & 0.75 & 0.6 & 0.75 & 0.75 & 0.6 & 0.7386 & 15 \\
\hline EFT-1 & 0.75 & 0.5 & 0.75 & 0.75 & 0.75 & 0.5 & 0.75 & - & - & 1 & 0.75 & 0.75 & 0.75 & 1 & 0.5 & 0.7521 & 11 \\
\hline EFT-2 & 0.75 & 0.75 & 0.75 & 0.75 & 0.5 & 0.75 & 1 & - & - & 1 & 0.75 & 0.75 & 0.75 & 0.75 & 0.75 & 0.7542 & 9 \\
\hline EFT-3 & 0.75 & 0.5 & 0.6 & 0.6 & 0.75 & 0.5 & 0.75 & - & - & 1 & 0.75 & 0.75 & 0.75 & 0.75 & 0.75 & 0.7474 & 13 \\
\hline EFT-4 & 0.5 & 0.5 & 0.75 & 0.75 & 0.5 & 0.5 & 1 & - & - & 0.75 & 0.75 & 0.75 & 0.75 & 0.75 & 0.75 & 0.7029 & 24 \\
\hline EFT-5 & 0.75 & 0.75 & 0.6 & 0.6 & 0.75 & 0.5 & 0.75 & - & - & 1 & 0.6 & 0.75 & 0.75 & 0.75 & 0.75 & 0.7526 & 10 \\
\hline TMS-1 & 0.75 & 0.75 & 0.75 & 0.75 & 0.75 & 0.75 & 0.75 & - & - & 1 & 0.75 & 0.75 & 0.75 & 0.75 & 1 & 0.7853 & 2 \\
\hline TMS-2 & 0.5 & 0.75 & 0.75 & 0.75 & 0.75 & 0.75 & 0.75 & - & - & 0.75 & 0.75 & 0.75 & 0.75 & 0.75 & 1 & 0.7697 & 4 \\
\hline TMS-3 & 0.75 & 0.75 & 0.75 & 0.75 & 0.75 & 0.75 & 0.75 & - & - & 1 & 0.75 & 0.75 & 0.75 & 1 & 1 & 0.8106 & 1 \\
\hline TMS-4 & 0.75 & 0.75 & 0.6 & 0.6 & 0.75 & 0.75 & 1 & - & - & 1 & 0.75 & 0.6 & 0.75 & 0.75 & 1 & 0.7654 & 5 \\
\hline TMS-5 & 0.75 & 0.75 & 0.75 & 0.75 & 0.75 & 0.75 & 0.75 & - & - & 1 & 0.75 & 0.6 & 0.75 & 0.75 & 1 & 0.7849 & 3 \\
\hline BIG-3 & 0.5 & 0.75 & 1 & 1 & 0.75 & 0.5 & 0.75 & - & - & 0.5 & 0.5 & 0.5 & 0.75 & 1 & 0.75 & 0.7352 & 18 \\
\hline BIG-4 & 0.42857 & 0.75 & 0.75 & 0.75 & 0.75 & 0.5 & 0.75 & - & - & 0.5 & 0.5 & 0.5 & 0.42857 & 0.75 & 0.75 & 0.7394 & 14 \\
\hline BIG-2 & 0.6 & 0.75 & 0.75 & 0.75 & 0.75 & 0.5 & 0.75 & - & - & 0.75 & 0.75 & 0.5 & 0.42857 & 1 & 1 & 0.7354 & 17 \\
\hline BIG-1 & 0.6 & 0.75 & 0.75 & 0.75 & 0.75 & 0.5 & 0.6 & - & - & 1 & 0.75 & 0.5 & 0.42857 & 0.75 & 1 & 0.7478 & 12 \\
\hline SS-1 & 1 & 0.75 & 0.75 & 0.6 & 0.375 & 0.75 & 0.6 & - & - & 0.75 & 0.75 & 1 & 0.75 & 0.75 & 0.5 & 0.7241 & 20 \\
\hline SS-2 & 0.75 & 0.75 & 0.75 & 0.6 & 0.375 & 0.75 & 0.6 & - & - & 0.75 & 0.75 & 0.75 & 0.75 & 0.75 & 0.5 & 0.7150 & 21 \\
\hline SS-3 & 1 & 0.75 & 1 & 0.6 & 0.6 & 0.75 & 0.75 & - & - & 1 & 0.5 & 0.75 & 0.75 & 0.75 & 0.5 & 0.7029 & 25 \\
\hline SS-4 & 1 & 0.75 & 0.75 & 0.6 & 0.5 & 0.75 & 0.75 & - & - & 0.75 & 0.75 & 0.75 & 0.75 & 1 & 0.6 & 0.7303 & 19 \\
\hline UDT-1 & 1 & 0.375 & 0.6 & 0.6 & 0.75 & 0.75 & 0.75 & - & - & 0.75 & 0.42857 & 0.75 & 0.75 & 0.75 & 0.375 & 0.6158 & 33 \\
\hline UDT-2 & 0.75 & 1 & 0.75 & 0.75 & 0.75 & 0.75 & 1 & - & - & 0.75 & 0.42857 & 0.75 & 0.75 & 0.75 & 0.75 & 0.7049 & 23 \\
\hline UDT-3 & 1 & 1 & 1 & 1 & 1 & 0.375 & 1 & - & - & 0.375 & 0.42857 & 0.75 & 0.75 & 0.75 & 0.75 & 0.7125 & 22 \\
\hline UDT-4 & 0.75 & 0.75 & 0.75 & 0.75 & 0.75 & 0.75 & 0.75 & - & - & 0.375 & 0.42857 & 0.75 & 0.75 & 0.75 & 0.75 & 0.6904 & 26 \\
\hline
\end{tabular}

\section{Managerial Implications and Conclusion}

In this work, we have sorted the obtained research outcomes by RIDIT and GRA as well as compared the positions of the questionnaire for their degree of importance from customers perspective. Here, we have observed that there is 
a positive connection between two methods i.e., RIDIT and GRA, both which are used to prioritize the service quality items in cooperative banks in India. The remarkable observation from the Table VI shows that 15 out of 33 ranks are assigned by the two techniques is matched and there is no significant difference with the rest of the ranks. Most of the times, Indian cooperative bank customers has given more importance to timeliness item with "Banker follows up in a timely manner to customer requests and problems". Indian cooperative banks have their image for late transactions or delayed activities. So, customers willingly expect to give more importance for timely services by the service providers. The second rank given by customers is "banks send and deposit on time money delivery" for their transactions as well as "when it comes to providing services as per promised time" with two methods respectively. The highest ranked scaled item includes the timely services offered to the customer by the cooperative bank managers.

The lowest ranked (RIDIT ranking 33) scaled items are "Cooperative bank employees manage the Speed of services" and (Grey ranking 33) "Customers and banking personnel's are interested to use/provide new electronic bank services. The slightest important dimension as per the positions obtained by the RIDIT \& GRA methods agrees to the effectiveness of the services and up to date technology. Since the customers are highly expecting the service providers to update their services based on present technology it is necessary for the service providers to focus and learn the same to increase the number of transactions. Service quality is an emerging strategic weapon in cooperative banking sector in India and it has also become a noteworthy tool to advance reasonable benefit in the sector. Due to high competition in Indian banking industry it is very much necessary for both the service providers and managers to differentiate themselves constantly by evaluating the dimensions of perceived service quality. Hence, by achieving better service quality ensures cooperative bank service providers to stay on top of the competition.

In this paper, we have applied a two way approach i.e RIDIT and GREY analysis to rank the service quality dimensions. The obtained results shows that there is a positive correlation between both the methods. The analysis reveals the positive correlation of 0.97291 between RIDIT and GREY methods which is significant at $\mathrm{p}=0.05$. The tests confirm, that there is no significant variance between RIDIT and GRA methods of ranking. This analysis shows that, the specific dimensions which are acknowledged as important may help for further study.

The present work is contributing few research findings which can be helpful to the literature study on cooperative bank service sector. It analysed the service quality by prioritising the cooperative banking service quality dimensions which are important in Indian banking sector for its own reasons. From this study, it is necessary that, the managers of cooperative banks in Indian scenario have to pay more attention to all service dimensions in order enhance their client's perception of banking service quality. The positive correlation between the rankings of service quality dimensions helps the managers to understand the necessity of to developing appropriate policies to improve the different aspects of their banking service quality.

Table 5. Grey values and ranking

\begin{tabular}{lll}
\hline Items & Grey Values & Rank \\
\hline EFF-1 & 0.67031 & 28 \\
\hline EFF-2 & 0.63018 & 32 \\
\hline EFF-3 & 0.65534 & 29 \\
\hline EFF-4 & 0.6415 & 31 \\
\hline EFF-5 & 0.64694 & 30 \\
\hline EFF-6 & 0.76134 & 7 \\
\hline INF-1 & 0.75463 & 8 \\
\hline INF-2 & 0.73843 & 16 \\
\hline INF-3 & 0.76513 & 6 \\
\hline INF-4 & 0.68734 & 27 \\
\hline INF-5 & 0.73857 & 15 \\
\hline EFT-1 & 0.75211 & 11 \\
\hline EFT-2 & 0.75422 & 9 \\
\hline
\end{tabular}




\begin{tabular}{lll}
\hline EFT-3 & 0.74743 & 13 \\
\hline EFT-4 & 0.70291 & 24 \\
\hline EFT-5 & 0.75261 & 10 \\
\hline TMS-1 & 0.78528 & 2 \\
\hline TMS-2 & 0.76968 & 4 \\
\hline TMS-3 & 0.8106 & 1 \\
\hline TMS-4 & 0.76541 & 5 \\
\hline TMS-5 & 0.78493 & 3 \\
\hline BIG-3 & 0.73518 & 18 \\
\hline BIG-4 & 0.73937 & 14 \\
\hline BIG-2 & 0.73543 & 17 \\
\hline BIG-1 & 0.7478 & 12 \\
\hline SS-1 & 0.72406 & 20 \\
\hline SS-2 & 0.71504 & 21 \\
\hline SS-3 & 0.70285 & 25 \\
\hline SS-4 & 0.73032 & 19 \\
\hline UDT-1 & 0.61579 & 33 \\
\hline UDT-2 & 0.67031 & 23 \\
\hline UDT-3 & 0.63018 & 22 \\
\hline UDT-4 & 0.65534 & 26 \\
\hline & &
\end{tabular}

Table 6. Comparision of RIDIT \& Grey Ranking

\begin{tabular}{lllll}
\hline Items & RIDIT Values & Rank & Grey Values & Rank \\
\hline EFF-1 & 0.570681203 & 28 & 0.67031 & 28 \\
\hline EFF-2 & 0.640006284 & 33 & 0.63018 & 32 \\
\hline EFF-3 & 0.595600821 & 29 & 0.65534 & 29 \\
\hline EFF-4 & 0.616362934 & 31 & 0.6415 & 31 \\
\hline EFF-5 & 0.610246846 & 30 & 0.64694 & 30 \\
\hline EFF-6 & 0.44885886 & 7 & 0.76134 & 7 \\
\hline INF-1 & 0.460158206 & 11 & 0.75463 & 8 \\
\hline INF-2 & 0.485379722 & 16 & 0.73843 & 16 \\
\hline INF-3 & 0.441259808 & 6 & 0.76513 & 6 \\
\hline INF-4 & 0.56188379 & 27 & 0.68734 & 15 \\
\hline INF-5 & 0.483255537 & 15 & 0.73857 & 11 \\
\hline EFT-1 & 0.45687809 & 10 & 0.75211 & 9 \\
\hline EFT-2 & 0.451967814 & 8 & 0.75422 & 13 \\
\hline EFT-3 & 0.462986337 & 12 & 0.74743 & 24 \\
\hline EFT-4 & 0.5365495 & 25 & 0.70291 & 10 \\
\hline EFCT-5 & 0.456056476 & 9 & 0.75261 & 2 \\
\hline TMS-1 & 0.405294363 & 3 & 0.78528 & \\
\hline
\end{tabular}




\begin{tabular}{lllll}
\hline TMS-2 & 0.429605681 & 4 & 0.76968 & 4 \\
\hline TMS-3 & 0.370125897 & 1 & 0.8106 & 1 \\
\hline TMS-4 & 0.435896824 & 5 & 0.76541 & 5 \\
\hline TMS-5 & 0.403595749 & 2 & 0.78493 & 3 \\
\hline BIG-3 & 0.488632312 & 18 & 0.73518 & 18 \\
\hline BIG-4 & 0.482353625 & 14 & 0.73937 & 14 \\
\hline BIG-2 & 0.487376619 & 17 & 0.73543 & 17 \\
\hline BIG-1 & 0.467787787 & 13 & 0.7478 & 12 \\
\hline SS-1 & 0.507006823 & 21 & 0.72406 & 20 \\
\hline SS-2 & 0.521637055 & 23 & 0.71504 & 21 \\
\hline SS-3 & 0.540168827 & 26 & 0.70285 & 19 \\
\hline SS-4 & 0.500171997 & 19 & 0.73032 & 33 \\
\hline UDT-1 & 0.636913401 & 32 & 0.61579 & 23 \\
\hline UDT-2 & 0.509117668 & 22 & 0.70486 & 22 \\
\hline UDT-3 & 0.502524787 & 20 & 0.7125 & 26 \\
\hline UDT-4 & 0.533675825 & 24 & 0.6904 &
\end{tabular}

\section{References}

Akdag, H. C., \& Zineldin, M. (2011). Strategic positioning and quality determinants in banking Service. The TQM Journal, 23(4), 446-457. https://doi.org/10.1108/17542731111139518

Amin, M., \& Isa, Z. (2008). An examination of the relationship between perception of service quality and customer satisfaction: a SEM approach towards Malaysian Islamic banks. International Journal of Islamic Middle Eastern Finance and Management, 1(3), 191-209. https://doi.org/10.1108/17538390810901131

Azam, M., Rahman, Z., Talib, F., \& Singh, K. J. (2012). A critical study of quality parameters in health care establishment: developing an integrated quality model. International Journal of Health Care Quality Assurance, 25(5), 387-402. https://doi.org/10.1108/09526861211235892

Bolton, R., \& Bronkhorst, T. (1995). The relationship between customer complaints to the firm and subsequent exit behavior. In F. R. Kardes, \& M. Sujan (Eds.), Advances in Consumer Research (Vol. 22, pp. 94-100). Association for Consumer Research, Provo, UT.

Boote, J. (1998). Towards a comprehensive taxonomy and model of consumer complaining behavior. Journal of Customer Satisfaction, Dissatisfaction and Complaining Behavior, 11, 141-149.

Bouman, M., \& Van der Wiele, T. (1992). Measuring service quality in the car services industry: building and testing an instrument. International Journal of Service Industry Management, 3(4), 4-16. https://doi.org/10.1108/09564239210019441

Bravo, R., Montaner, T., \& Pina, J. M. (2009). The role of bank image for customers versus noncustomers. International Journal of Bank Marketing, 27(4), 315-334. https://doi.org/10.1108/02652320910968377

Butt, M. M., \& De Run, E. C. (2010). Private healthcare quality: applying a SERVQUAL model. International Journal of Health Care Quality Assurance, 23(7), 658-673. https://doi.org/10.1108/09526861011071580

Choudhury, K. (2013). Service quality and customers' purchase intentions: an empirical study of the Indian banking sector. International Journal of Bank Marketing, 31(7), 529-543. https://doi.org/10.1108/IJBM-02-2013-0009

Colgate, M., \& Hedge, R. (2001). An investigation into the switching process in retail banking services. International Journal of Bank Marketing, 19(5), 201-212. https://doi.org/10.1108/02652320110400888

Cronin, J. J., \& Taylor, S. A. (1992). Measuring service quality: a re-examination and extension. Journal of Marketing, 56(3), 55-68. https://doi.org/10.1177/002224299205600304

Ekinci, Y., \& Riley, M. (1999). Measuring hotel quality: back to basics. International Journal of Contemporary 
Hospitality Management, 11(6), 287-294. https://doi.org/10.1108/09596119910281775

Flavian, C., Torres, E., \& Guinaliu, M. (2004). Corporate image measurement: a further problem for the tangibilization of internet banking services. International Journal of Bank Marketing, 22(5), 366-384. https://doi.org/10.1108/02652320410549665

Gagliano, K. B., \& Hathcote, J. (1994). Customer expectations and perceptions of service quality in apparel retailing. Journal of Services Marketing, 8(1), 60-69. https://doi.org/10.1108/08876049410053311

Garland, R. (2002). Estimating customer defection in personal retail banking. International Journal of Bank Marketing, 20(7), 317-324. https://doi.org/10.1108/02652320210451214

Hsiong-Ming, L., Ching-Chi, L., \& Cou-Chen, W. (2011). Brand image strategy affects brand equity after M \& A. European Journal of Marketing, 45(7/8), 1091-1111. https://doi.org/10.1108/03090561111137624

Kang, G.-D., \& James, J. (2004). Service quality dimensions: an examination of Gronroos's service quality model. Managing Service Quality, 14(4), 266-277. https://doi.org/10.1108/09604520410546806

Kennedy, S. H. (1977). Nurturing corporate image. European Journal of Marketing, 11(3), 120-164. https://doi.org/10.1108/EUM0000000005007

Levesque, T., \& McDougall, G. H. G. (1996). Determinants of customer satisfaction in retail banking. International Journal of Bank Marketing, 14(7), 12-20. https://doi.org/10.1108/02652329610151340

Nguyen, N., \& LeBlanc, G. (2001). Corporate image and corporate reputation in customers' retention decisions in services. Journal of Retailing and Consumer Services, 8, 227-236. https://doi.org/10.1016/S0969-6989(00)00029-1

Panda, R. K., \& Kondasani, R. K. R. (2014). 'Assessing customers' perceived service quality in private sector banks in India. Serbian Journal of Management, 9(1), 91-103. https://doi.org/10.5937/sjm9-4511

Parasuraman, A., Zeithaml, V. A., \& Berry, L. L. (1985). A conceptual model of service quality and its implication for future research. Journal of Marketing, 49(4), 41-50. https://doi.org/10.1177/002224298504900403

Parasuraman, A., Zeithaml, V. A., \& Berry, L. L. (1988). SERVQUAL: a multiple-item scale for measuring consumer perceptions of service quality. Journal of Retailing, 64(1), 12-140.

Phimoolchat, J., \& Muttamara, A. (2020). Multi-objective optimization of electrical discharge machining parameters for 2024 aluminum alloy using grey-taguchi method. In Materials Science Forum (Vol. 998, pp. 55-60). Trans Tech Publications Ltd. https://doi.org/10.4028/www.scientific.net/MSF.998.55

\section{Appendix}

\begin{tabular}{|c|c|c|}
\hline Factor Name & Item & Item Code \\
\hline \multirow{6}{*}{$\begin{array}{l}\text { Efficiency } \\
(\mathrm{EFF})\end{array}$} & Queuing time at the bank is minimal & EFF-1 \\
\hline & Cooperative bank employees manage the Speed of services & EFF-2 \\
\hline & $\begin{array}{l}\text { Bank is having skilful and experienced workers and staff individuals to handle } \\
\text { clients easily }\end{array}$ & EFF-3 \\
\hline & $\begin{array}{l}\text { Bank representatives and staff carry out their responsibility productively till the } \\
\text { closing hours }\end{array}$ & EFF-4 \\
\hline & $\begin{array}{l}\text { The current banking administration system is user friendly to the customers, so } \\
\text { that employees administer perfectly }\end{array}$ & EFF-5 \\
\hline & Turnaround time for receiving bank services is adequate & EFF-6 \\
\hline \multirow{4}{*}{$\begin{array}{l}\text { Infrastructure } \\
\text { (INF) }\end{array}$} & Modern equipment is used in this bank & INF-1 \\
\hline & Bank's Inside environment is visually appealing decoration & INF-2 \\
\hline & Layout of the bank furniture is well planned & INF-3 \\
\hline & Bank has adequate parking facilities & INF-4 \\
\hline
\end{tabular}




\begin{tabular}{|c|c|c|}
\hline & Bank building is attractive & INF-5 \\
\hline \multirow{5}{*}{$\begin{array}{l}\text { Effectiveness } \\
(\mathrm{EFT})\end{array}$} & Bank offers friendly and personalised services to customers & EFT-1 \\
\hline & Customer retention capability is better than their competitors & EFT-2 \\
\hline & $\begin{array}{l}\text { Bank employee's ability to acquire new customers and retaining present } \\
\text { customers is better than other banks }\end{array}$ & EFT-3 \\
\hline & $\begin{array}{l}\text { if required, bank employees will make personal sacrifices to serve their } \\
\text { customers }\end{array}$ & EFT-4 \\
\hline & $\begin{array}{l}\text { All departments in the bank are well cooperated to complete tasks more } \\
\text { efficiently }\end{array}$ & EFT-5 \\
\hline \multirow{5}{*}{$\begin{array}{l}\text { Timely Services } \\
\text { (TMS) }\end{array}$} & Providing services as per the promised time & TMS-1 \\
\hline & Bank services are accurate even at the first attempt & TMS-2 \\
\hline & Banker follows up the customer requests and problems at time to time & TMS-3 \\
\hline & $\begin{array}{l}\text { The manner and method of communication between banker and customer are } \\
\text { timely and accurate }\end{array}$ & TMS-4 \\
\hline & Bank send and deposit on time money delivery & TMS-5 \\
\hline \multirow{5}{*}{$\begin{array}{l}\text { Bank Image } \\
\text { (BIG) }\end{array}$} & Cooperative bank have competent and efficient staff reputation & BIG-3 \\
\hline & Have an account in this bank is a status symbol for customers & BIG-1 \\
\hline & Cooperative banks have positive image in the customer mind & BIG-2 \\
\hline & Cooperative bank have competent and efficient staff reputation & BIG-3 \\
\hline & Cooperative banks offer attractive products and services & BIG-4 \\
\hline \multirow{4}{*}{$\begin{array}{l}\text { Safety \& Security } \\
\text { (SS) }\end{array}$} & The bank I am using the services is safe & SS-1 \\
\hline & Bank is offering safety and security for all of its financial transactions & SS-2 \\
\hline & Personal and financial data are secured in this bank & SS-3 \\
\hline & Bank Employees desk and table are comfortable for the customers & SS-4 \\
\hline \multirow{4}{*}{$\begin{array}{l}\text { Up to } \\
\text { technology } \\
\text { (UDT) }\end{array}$} & $\begin{array}{l}\text { Customers and banking personnel's are interested to use/provide new } \\
\text { electronic bank services }\end{array}$ & UDT-1 \\
\hline & Latest technology of banking gives customer a better overview of finances & UDT-2 \\
\hline & Trouble-free cash dispenser are attached with the bank & UDT-3 \\
\hline & $\begin{array}{l}\text { Bank regularly collect and utilise customer information to provide customised } \\
\text { products to their customers }\end{array}$ & UDT-4 \\
\hline
\end{tabular}

\section{Copyrights}

Copyright for this article is retained by the author(s), with first publication rights granted to the journal.

This is an open-access article distributed under the terms and conditions of the Creative Commons Attribution license (http://creativecommons.org/licenses/by/4.0/). 